\title{
1,4-Dideoxy-1,4-imino-D-arabinitol (DAB) Analogues Possessing a Hydrazide Imide Moiety as Potent and Selective $\alpha$-Mannosidase Inhibitors
}

\author{
Marianne B. Haarr, Óscar Lopéz, Ljupcho Pejov, José G. Fernández-Bolaños, Emil Lindbäck,* \\ and Magne O. Sydnes*
}

Cite This: ACS Omega 2020, 5, 18507-18514

Read Online

ABSTRACT: The synthesis of two polyhydroxylated pyrrolidines as 1,4-dideoxy-1,4-imino-D-arabinitol (DAB) analogues bearing a hydrazide moiety is described. The $\mathrm{DAB}$ analogues act as selective and potent inhibitors of $\alpha$-mannosidase in the submicromolar concentration ranges ( $K_{\mathrm{i}}$ values ranging from 0.23 to $\left.1.4 \mu \mathrm{M}\right)$.

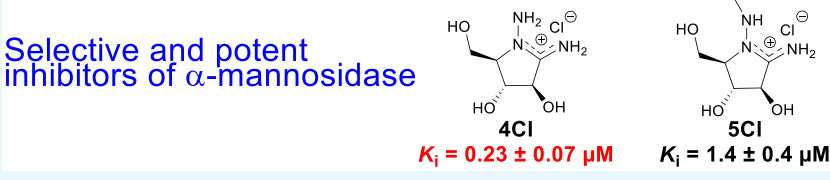

\section{INTRODUCTION}

Glycosidases represent a group of enzymes that is abundant in essentially all living organisms, in which they catalyze the hydrolysis of glycosidic bonds. ${ }^{1}$ Such hydrolases are, for instance, involved in the intestinal digestion of starch, the biosynthesis of oligosaccharide chains, and the hydrolysis of glycoconjugates in the lysosomes. Thus, the diverse biological roles of glycosidases have labeled glycosidase inhibitors as attractive pharmaceutical targets. ${ }^{2}$

The most common type of glycosidase inhibitor is azasugars (such as isofagomine (1) (Figure 1)) and iminosugars, in

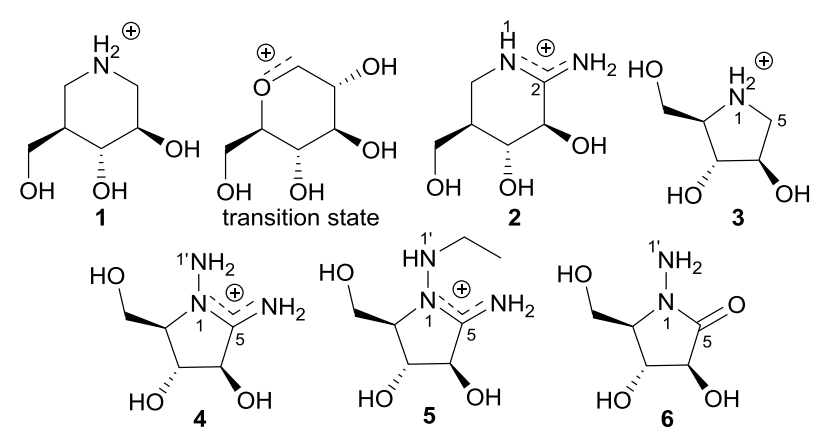

Figure 1. Compounds $1-3$ and the target compounds $4-6$ in this project.

which a carbon atom or the endocyclic oxygen atom in a saccharide has been replaced by a nitrogen atom, respectively. ${ }^{3}$ Currently, three iminosugars, namely, Glyset ( $\mathrm{N}$-(2-hydroxyethyl)-1-deoxynojirimycin), ${ }^{4}$ Zavesca ( $N$-butyl-1-deoxynojirimycin), ${ }^{5}$ and Galafold (1-deoxygalactonojirimycin), ${ }^{6}$ are marketed for the treatment of type 2 diabetes, Gaucher disease, and Fabry disease, respectively. In addition, due to their glycosidase inhibitory properties, aza- and iminosugars serve as lead compounds for the treatment of diseases such as diabetes, cancer, viral infections, and lysosomal storage disorders. ${ }^{7}$ However, in many cases, a limitation of iminosugars as drug candidates is that they display low glycosidase inhibition selectivity and thus they interact with glycosidases that are not involved in the disease that they are targeted to tackle; ${ }^{8}$ as a result, severe side effects can be triggered when this lack of selectivity is present.

Aza- and iminosugars are believed to act as glycosidase inhibitors due to their ability to be protonated at physiological $\mathrm{pH}$ and thus resemble the charge in the transition state of glycosidase-catalyzed cleavage of glycosidic bonds. ${ }^{9}$ Aza- and iminosugars have therefore been used as tools to explore the mechanism of glycosidases. ${ }^{10}$ Thus, many aza- and iminosugars have been designed and synthesized to resemble the charge and/or shape of the transition state of catalyzed cleavage of glycosidic bonds. ${ }^{10,11}$ One such example is isofagomine (1), which was found to be a very potent inhibitor of $\beta$-glucosidase $\left(K_{\mathrm{i}}, 0.11 \mu \mathrm{M}\right) .^{12}$ Interestingly, X-ray analysis of a cellobioderived isofagomine in complex with Cel5A confirmed that the isofagomine derivative is bound to the enzyme in its protonated form and as such establishes an ion-ion interaction with the catalytic nucleophile. ${ }^{13}$ The importance of ion-ion interactions between the enzyme and the inhibitor and Ganem et al.'s hypothesis that sugar amidines behave as broad spectrum glycosidase inhibitors because they resemble the shape of the transition state of enzymatic cleavage of glycosides, ${ }^{14}$ even though the full understanding of the features of the transition state of such enzymes is missing, ${ }^{15}$ led to the

Received: May 26, 2020

Accepted: June 30, 2020

Published: July 15, 2020 
synthesis of an amidine analogue of isofagomine, namely, isofagomidine (2). ${ }^{16}$ This compound was found to display a very narrow glycosidase inhibitory spectrum along with a very different glycosidase inhibition profile compared to isofagomine (1). Indeed, 2 was found to be a selective inhibitor $\left(K_{\mathrm{i}}\right.$, $0.75 \mu \mathrm{M})$ of jack-bean $\alpha$-mannosidase, which is a member of the retaining glycosidase hydrolase family 38 that includes $\alpha$ mannosidases with medicinal relevance. ${ }^{17}$ The difference in the glycosidase inhibition profile between $\mathbf{1}$ and $\mathbf{2}$ was supported by DFT calculations and was attributed to a very different charge distribution within the two compounds in their protonated forms. ${ }^{16}$

Many polyhydroxylated pyrrolidines such as 1,4-dideoxy-1,4imino-D-arabinitol (DAB, 3) (Figure 1) have been found to be potent glycosidase inhibitors. ${ }^{7,18}$ In addition, many of them inhibit a rather broad spectra of glycosidases, which has been attributed to the flexibility of the five-membered ring system ${ }^{19}$ including, in some cases, their ability to form a half chairlike conformation. $^{20}$

$\mathrm{DAB}$ (3) has been found to display inhibition of various types of $\alpha$-glucosidases. ${ }^{21}$ However, it has been shown that selectivity for other glycosidases can be achieved upon chemical modifications. ${ }^{22}$ Thus, as part of our ongoing research on sugar hydrazide imides, ${ }^{23}$ we wanted to investigate whether the insertion of a hydrazide imide moiety into DAB to obtain arabinohydrazide imides $\mathbf{4}$ and $\mathbf{5}$ would have any impact on the inhibition profile as was the case when isofagomine (1) was converted into its corresponding amidine 2 . In this paper, we present the synthesis of 4, 5, and 6 and DFT calculations shedding light on their charge distribution, in addition to their glycosidase inhibitory activity.

\section{RESULTS AND DISCUSSION}

The synthesis of hydrazide imides $\mathbf{4 C l}$ and $\mathbf{5 C l}$ commenced from 2,3,5-tri-O-benzyl-L-xylofuranose (7) (Scheme 1), which in turn was obtained from L-xylose in three steps by following reported procedures. ${ }^{24}$ Thus, by following a protocol reported by Ermert and Vasella for the synthesis of 2,3,4,6-tetra-O-

Scheme 1. Synthesis of D-Arabinohydrazide Imides $4 \mathrm{Cl}$ and $5 \mathrm{Cl}$

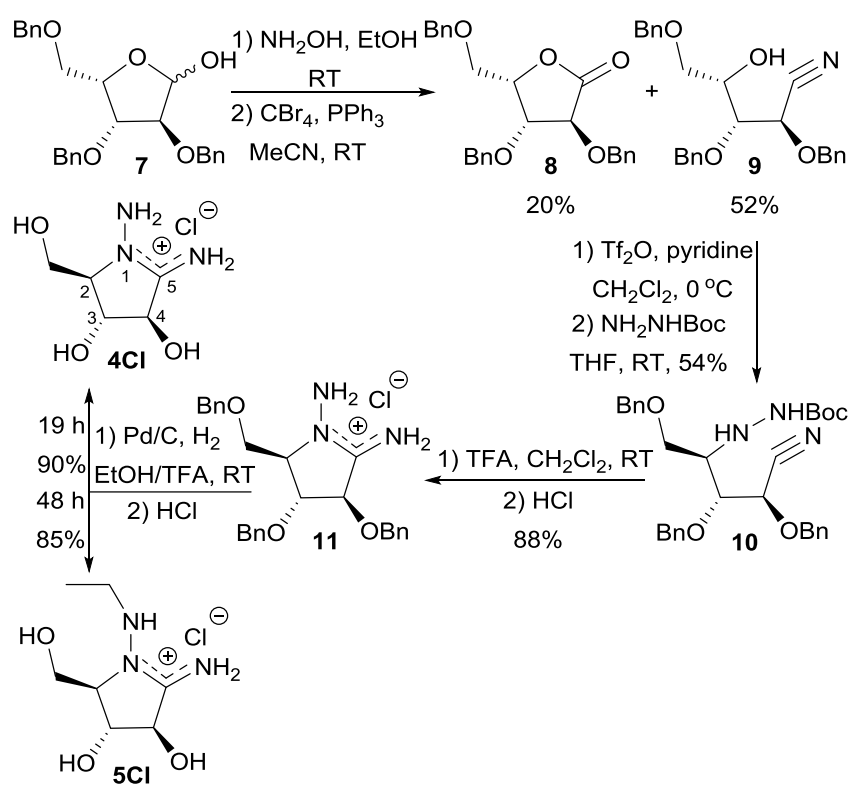

benzyl-D-glucononitrile, ${ }^{25}$ condensation of 7 with hydroxyl amine to provide an aldoxime intermediate followed by dehydration under Appel conditions provided nitrile 9 in $52 \%$ yield along with known L-xylonolactone $8 .{ }^{26}$ In the subsequent step, compound 9 underwent stereospecific hydrazidation into hydrazide $\mathbf{1 0}$ in 54\% yield involving triflation of the free hydroxyl group on $\mathrm{C} 4$ followed by treatment with Boc-hydrazide. TFA-promoted removal of the Boc-protective group activated the cyclization into hydrazide imide 11 after treatment with $\mathrm{HCl}$. The benzyl protective groups were removed by palladium-catalyzed hydrogenation in EtOH/TFA to provide hydrazide imide $\mathbf{4 C l}$ after counterion exchange with $\mathrm{HCl}$. In order to exclude any unexpected epimerization in the synthesis of $\mathbf{4 C l}$, a NOESY experiment was conducted, which showed interaction between the protons in the 2- and 4-position as expected. Interestingly, when the hydrogenation time was extended from 19 to $48 \mathrm{~h}$, the $N$-ethyl hydrazide imide $\mathbf{5 C l}$ was obtained in $85 \%$ yield. Similar $N$ ethylation observations have been made both by Jensen and co-workers $^{27}$ and Sydnes and Isobe ${ }^{28}$ when ethanol was employed as a solvent for palladium-catalyzed hydrogenation to remove benzyl groups from iminosugars and to reduce nitrobenzenes, respectively. In the latter case, it was proposed that acetaldehyde was the alkylating agent formed through a $\beta$ hydride elimination mechanism, first proposed by Sajiki and co-workers. $^{29}$

We also attempted to obtain sugar hydrazide imide 12 (Scheme 2), with a six-membered ring system. Thus, the

Scheme 2. Synthesis of Hydrazide $6 \mathrm{HCl}$ and Attempted Synthesis of Hydrazide Imide 12

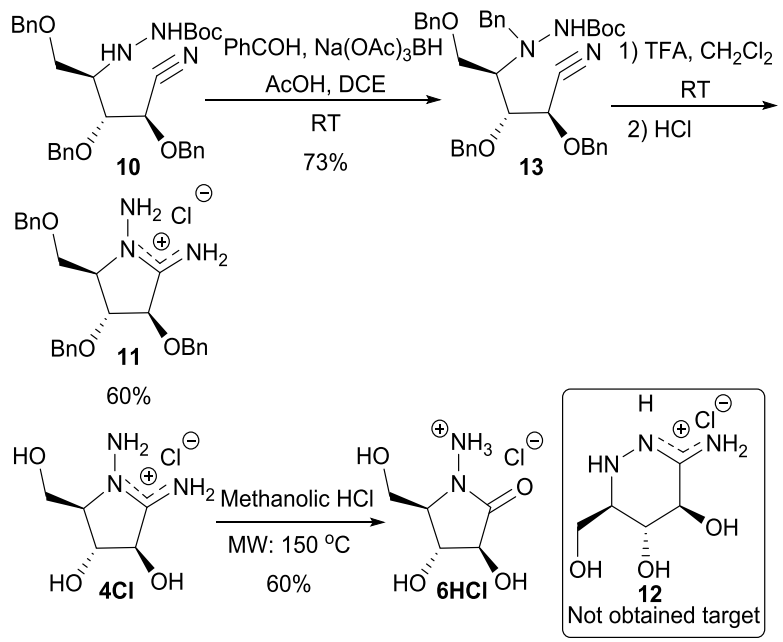

amino group of hydrazide $\mathbf{1 0}$ was benzyl-protected into compound 13 upon reductive amination with benzaldehyde and sodium triacetoxyborohydride. Unfortunately, TFApromoted removal of the Boc-protective group triggered the cyclization into the five-membered ring system 11 and not the six-membered ring as anticipated. We also envisaged that $4 \mathrm{Cl}$ should rearrange into $\mathbf{1 2}$ via an imidate intermediate upon treatment with $\mathrm{HCl}$ in methanol. However, when $4 \mathrm{Cl}$ was treated with methanolic $\mathrm{HCl}$ at elevated temperature, we did not observe any reaction. When we attempted the same reaction in the microwave at $150{ }^{\circ} \mathrm{C}$, we realized that $4 \mathrm{Cl}$ underwent hydrolysis into the corresponding hydrazide $6 \mathrm{HCl}$ in $60 \%$ yield. 
Compounds $4 \mathrm{Cl}, \mathbf{5 C l}$, and $\mathbf{6 H C l}$, in addition to positive reference compounds isofagomine (1) and 1-deoxynojirimycin $(\mathrm{DNJ})$, underwent screening as glycosidase inhibitors on a panel of commercial glycosidases including $\alpha$-glucosidase ( Saccharomyces cerevisiae), $\beta$-glucosidase (almonds), $\alpha$-galactosidase (green coffee beans), $\beta$-galactosidase (Aspergillus oryzae), $\beta$-galactosidase (Escherichia coli), $\alpha$-mannosidase (jack beans), and $\beta$-mannosidase (Helix pomatia) (Table 1). The inhibition data demonstrate clearly that the inhibition profile for hydrazide imides $4 \mathrm{Cl}$ and $5 \mathrm{Cl}$ and compound $6 \mathrm{HCl}$ is very different from that of $\mathrm{DAB}$ (3) with respect to $\beta$ glucosidase activity. In contrast to 3 , which behaves as a micromolar inhibitor for $\beta$-glucosidase, ${ }^{22} 4 \mathrm{Cl}, 5 \mathrm{Cl}$, and $6 \mathrm{HCl}$ display no or very low inhibition of that enzyme. Comparison of the inhibition profiles for $\mathbf{4 C l}$ and $\mathbf{5 C l}$ with isofagomidine (2) demonstrates that they are very similar and display competitive inhibition of $\alpha$-mannosidase down to the submicromolar concentration range $\left(K_{\mathrm{i}}=0.23 \mu \mathrm{M}\right.$ for $\left.4 \mathrm{Cl}\right)$, indicating the profit of a hydrazide imide or amidine moiety for the binding to the enzyme. The only difference in the inhibition profile between hydrazide imides $4 \mathrm{Cl}$ and $\mathbf{5 C l}$ differing in only one $\mathrm{N}$-ethyl group is that the former behaves as a competitive inhibitor for $\alpha$-glucosidase in the micromolar concentration range. Moreover, alkylation of the exocyclic nitrogen atom furnishes a roughly 6-fold impairment in the activity against $\alpha$-mannosidase. These data mean that a high degree of selectivity was achieved in both $\mathrm{DAB}$ analogues, with a selectivity index ranging from 22 to $>400$; accordingly, severe side effects derived from the unselective inhibitory profile of many other iminosugars can be avoided. The selectivity toward $\alpha$-mannosidase inhibition by $\mathbf{4 C l}$ and $\mathbf{5 C l}$ is interesting from a medicinal perspective, given that $\alpha$-mannosidase is a relevant target against tumorigenic processes. ${ }^{30}$

In order to gain more insight into the different inhibition profile for hydrazide imides $4 \mathrm{Cl}$ and $5 \mathrm{Cl}$ compared to $6 \mathrm{HCl}$, the charge distribution within the systems 3-6 was calculated employing the Mulliken partitioning scheme as well as by fitting atom-centered point charges to reproduce the molecular electrostatic potential with different schemes (Table 2). Due to the electronic similarities between sugar amidrazones with a $\mathrm{p} K_{\mathrm{a}}$ of 8.7 and our hydrazide imides 4 and 5 , $^{31}$ we assumed that they exist in their acidic forms in the calculations since the glycosidase inhibitory testing was performed at $6.8 \geq \mathrm{pH}(6.8$ for glucosidases and galactosidases and 5.6 for mannosidases). For compounds 4-6, the atomic charge for N1 varied from essentially zero up to positive values. The functional group charges for $\mathrm{NH}_{2} 1^{\prime}$ in 4 and 6 and $\mathrm{NH}^{\prime}$ in 5 were less consequent as they varied from negative up to positive values. The most striking difference between hydrazide amides 4 and 5 compared to hydrazide $\mathbf{6}$ is that $\mathbf{4}$ and $\mathbf{5}$ host a positively charged $\mathrm{NH}_{2} 5$ group in the position in which 6 contains an oxygen (O5) with a negative atomic charge. Thus, the difference in charge distribution between 4 and 5 compared to 6 might be the reason for their different inhibition profiles. In addition, because 4 and 5 possess very similar charge distributions, we propose that the $N$-ethyl group of $\mathbf{5}$ disrupts its binding to $\alpha$-glucosidase as $\mathbf{4}$ binds to the same enzyme in the micromolar concentration range. Another interesting observation was made when 4 and 5 was compared with isofagomidine (2), ${ }^{16}$ another $\alpha$-mannosidase selective inhibitor; it was observed that this compound in line with $\mathbf{4}$ and 5 also possesses an exocyclic $\mathrm{NH}_{2}$ group $\left(\mathrm{NH}_{2} 2\right)$, which hosts a positive functional group charge. Note that the atomic charges

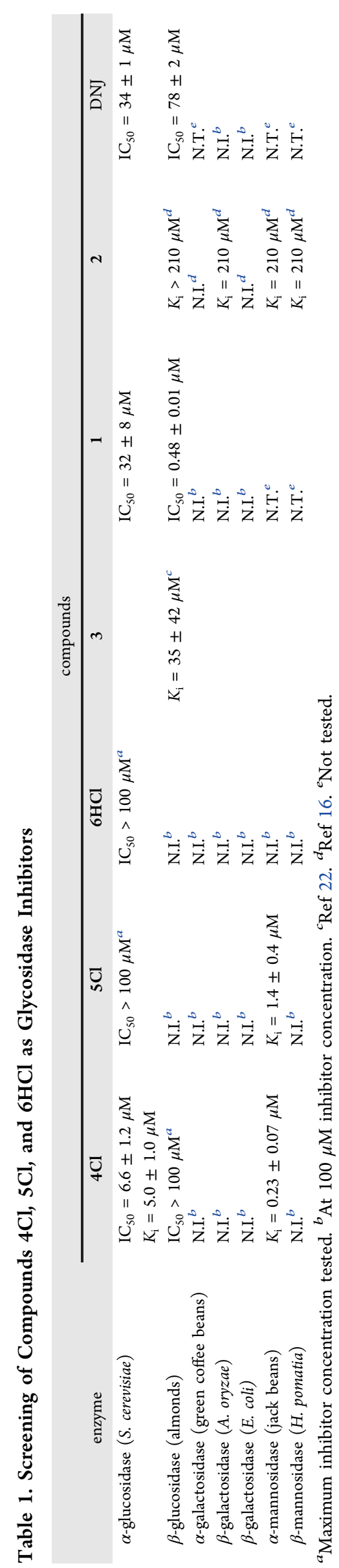


Table 2. Calculation of Charge Distribution within 2-6

$\begin{array}{clccl}\text { comp. } & \mathrm{N1}^{a} / \mathrm{NH}_{2} 1^{b} & \mathrm{NH}_{2} 1^{\prime c} / \mathrm{NH}^{\prime d} & \mathrm{C} 5 & \mathrm{NH}_{2} 5^{e} / \mathrm{O}^{f} \\ \mathbf{4} & +0.16^{g} & -0.01 & +0.54 & +0.16 \\ & +0.18^{h} & 0.00 & +0.22 & +0.17 \\ & +0.08^{j} & +0.18 & +0.27 & +0.37 \\ \mathbf{5} & +0.07 & -0.31 & +0.54 & +0.10 \\ & -0.05 & -0.27 & +0.53 & +0.10 \\ & +0.23 & +0.14 & +0.46 & +0.36 \\ 6 & +0.29 & -0.12 & +0.50 & -0.55 \\ & +0.08 & -0.08 & +0.51 & -0.56 \\ & -0.09 & +0.29 & +0.28 & -0.33 \\ 3 & +0.21 & & -0.04 & \\ & +0.20 & & 0.09 & \\ & +0.61 & & -0.40 & \\ 2^{j} & -0.1^{i}(\mathrm{NH} 1) & & 0.5(\mathrm{C} 2) & 0.1\left(\mathrm{NH}_{2} 2\right)\end{array}$

${ }^{a}$ 4-6. ${ }^{b}$ 3. ${ }^{c} \mathbf{4}$ and $6 .{ }^{d} 5 .{ }^{e}$ and $5 .{ }^{f} 6 .{ }^{g}$ HLY. ${ }^{h}$ CHelpG. ${ }^{i}$ Mulliken. ${ }^{j}$ Ref 16. All calculations have been done at the B3LYP/6-311++G $(d, p)$ level of theory (for the geometries optimized at the same level, see the Experimental Section for further technical details).

reported for $2^{16}$ have been computed with the same DFT method but using a smaller basis set for orbital expansion (6$31 \mathrm{G}$ ) so that a direct comparison with the data from our current study is somewhat hampered.

Based on the calculated charge distributions and the coupling constants between the ring protons in the ${ }^{1} \mathrm{H}$ NMR spectra, we expect compounds $4 \mathrm{Cl}$ and $\mathbf{5 C l}$ to anticipate a ${ }^{3} E$ conformation (Figure 2). However, the coupling constants

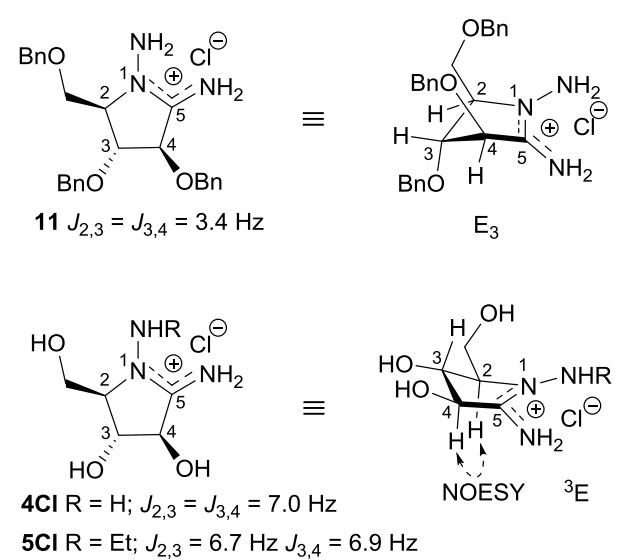

Figure 2. Suggested envelope conformations of compounds $4 \mathrm{Cl}, \mathbf{5 C l}$, and 11.

between the ring protons in the benzyl-protected counterpart 11 are significantly smaller, which could signify an $E_{3}$ conformation. A more in-depth study of conformational dependence on charge distribution and spin-spin coupling constants in the present molecular systems is in progress.

\section{CONCLUSIONS}

In the work presented herein, we obtained two 1,4-dideoxy1,4-imino-D-arabinitol (DAB) analogues $4 \mathbf{C l}$ and $\mathbf{5 C l}$ possessing a hydrazide imide. These two compounds behave as selective $\alpha$-mannosidase inhibitors down to $K_{\mathrm{i}}=230 \mathrm{nM}$. When comparing $\mathbf{4} \mathbf{C l}$ and $\mathbf{5 C l}$, two observations were made: the $N$-ethyl group of $\mathbf{5 C l}$ slightly impaired the inhibition of $\alpha$ mannosidase and the same group had a positive influence for the selectivity toward $\alpha$-mannosidase.

\section{EXPERIMENTAL SECTION}

General Information. All chemicals were obtained from Sigma Aldrich/Merck or VWR and used as supplied. When specified, solvents were dried by storing over $4 \AA$ molecular sieves. For petroleum ether (PE), the $40-65{ }^{\circ} \mathrm{C}$ fraction was used. All reactions were carried out under a nitrogen or argon atmosphere, unless otherwise specified. TLC analyses were performed on Merck silica gel 60 F254 plates using UV light, $\mathrm{KMnO}_{4}$, or heat for detection. Silica gel NORMASIL $6040-$ $63 \mu \mathrm{m}$ was used for flash column chromatography. Nuclear magnetic resonance (NMR) spectra were recorded on a Bruker AscendTM 400 series, operating at $400.13 \mathrm{MHz}$ for ${ }^{1} \mathrm{H}$ and $100.61 \mathrm{MHz}$ for ${ }^{13} \mathrm{C}$ in $\mathrm{CDCl}_{3}, \mathrm{CD}_{3} \mathrm{OD}, \mathrm{D}_{2} \mathrm{O}$, or DMSO- $d_{6}$. The assignment of signals in all NMR spectra was assisted by conducting ${ }^{1} \mathrm{H}-{ }^{1} \mathrm{H}$ correlation spectroscopy, ${ }^{1} \mathrm{H}-{ }^{13} \mathrm{C} /{ }^{1} \mathrm{H}-{ }^{15} \mathrm{~N}$ heteronuclear single-quantum correlation spectroscopy, and/or ${ }^{1} \mathrm{H}-{ }^{13} \mathrm{C} /{ }^{1} \mathrm{H}-{ }^{15} \mathrm{~N}$ heteronuclear multiple bond correlation spectroscopy. Chemical shifts $(\delta)$ are reported in ppm relative to an internal standard of residual chloroform $(\delta=7.26 \mathrm{ppm}$ for ${ }^{1} \mathrm{H}$ NMR; $\delta=77.16$ ppm for ${ }^{13} \mathrm{C}$ NMR), residual methanol $\left(\delta=3.31 \mathrm{ppm}\right.$ for ${ }^{1} \mathrm{H}$ NMR; $\delta=49.00 \mathrm{ppm}$ for $\left.{ }^{13} \mathrm{C} \mathrm{NMR}\right)$, residual dimethyl sulfoxide ( $\delta=2.50 \mathrm{ppm}$ for ${ }^{1} \mathrm{H}$ NMR; $\delta=$ $39.52 \mathrm{ppm}$ for $\left.{ }^{13} \mathrm{C} \mathrm{NMR}\right)$, or residual water $(\delta=4.79 \mathrm{ppm}$ for ${ }^{1} \mathrm{H}$ NMR). Infrared spectroscopy (IR) was performed on a Cary 360 FTIR spectrophotometer. High-resolution mass spectra (HRMS) were recorded from $\mathrm{MeOH}$ solutions on a JMS-T100LC AccuTOFTM in positive electrospray ionization (ESI) mode. The microwave-assisted experiments were performed in a CEM Focused Microwave Synthesis System, model type Discover, operating at $0-300 \mathrm{~W}$ at a temperature of $118{ }^{\circ} \mathrm{C}$ and a pressure range of $0-290 \mathrm{psi}$, with reactor vial volumes of $10 \mathrm{~mL}$.

2,3,5-Tri-O-benzyl-L-xylofuranose (7). Step 1: To a solution of $\mathrm{AcCl}(0.29 \mathrm{~mL}, 4 \mathrm{mmol})$ in $\mathrm{MeOH}(40 \mathrm{~mL})$ was added Lxylose $(3 \mathrm{~g}, 20 \mathrm{mmol})$ at rt. The reaction mixture was kept stirring at $\mathrm{rt}$ for $5.5 \mathrm{~h}$. The reaction mixture was then cooled to $0{ }^{\circ} \mathrm{C}$, and $\mathrm{pH}$ was adjusted to ca. 9 with $\mathrm{NaOH}(1 \mathrm{M})$. The solvent was then removed under reduced pressure, and the resulting residue was suspended in toluene $(6 \times 10 \mathrm{~mL})$ and concd to dryness. Step 2: The residue from step 1 was dissolved in dry DMF (64 mL), and $\mathrm{NaH}$ (4.24 g, 5.3 equiv) was added at rt. The reaction mixture was then cooled to $0{ }^{\circ} \mathrm{C}$ prior to addition of $\mathrm{BnBr}(11.9 \mathrm{~mL}, 5$ equiv). The reaction mixture was stirred at $\mathrm{rt}$ for $23 \mathrm{~h}$ before being extracted with EtOAc $(2 \times 75 \mathrm{~mL})$. The combined extracts were dried over $\mathrm{MgSO}_{4}$ and concd in vacuo. Step 3: The residue from step 2 was dissolved in dioxane $(60 \mathrm{~mL})$ and $\mathrm{HCl}(60 \mathrm{~mL}, 4 \mathrm{M})$ and stirred at $65{ }^{\circ} \mathrm{C}$ for 4 days. The reaction mixture was then extracted with EtOAc $(2 \times 75 \mathrm{~mL})$, and the combined organic fractions were concentrated and subjected to flash column chromatography (PE/EtOAc, 17:3 $\rightarrow 3: 1)$. Collection of the appropriate fractions $\left(R_{\mathrm{f}}=0.25 ; \mathrm{PE} / \mathrm{EtOAc}, 3: 1\right)$ provided compound 7 (4.97 g, 59\%) as a clear light-yellow oil. The spectroscopic data were in full accord with the previously reported data. $^{23}$

2,3,5-Tri-O-benzyl-L-xylononitrile (9). Step 1: To a solution of $\mathrm{Na}$ (315 mg, $13.7 \mathrm{mmol})$ dissolved in absolute EtOH (60 $\mathrm{mL})$ was added $\mathrm{NH}_{2} \mathrm{OH} \cdot \mathrm{HCl}(1.77 \mathrm{~g}, 27.5 \mathrm{mmol})$. The reaction mixture was stirred at $\mathrm{rt}$ for $5 \mathrm{~min}$ before a solution of furanose $7(1.44 \mathrm{~g}, 3.42 \mathrm{mmol})$ in absolute $\mathrm{EtOH}(11 \mathrm{~mL})$ was added. The resulting reaction mixture was stirred at $\mathrm{rt}$ for $1 \mathrm{~h}$ before volatiles were removed by reduced pressure. To the 
residue were then added water $(50 \mathrm{~mL})$ and EtOAc $(50 \mathrm{~mL})$. The two phases were separated, and the aq phase was extracted with EtOAc $(2 \times 50 \mathrm{~mL})$. The combined organic fractions were dried with $\mathrm{MgSO}_{4}$, filtered, and concentrated in vacuo. The residue $\left(R_{\mathrm{f}}=0.4 ; \mathrm{PE} / \mathrm{EtOAc}, 3: 2\right)$ was dissolved in toluene, concentrated, and used directly in the following step. Step 2: To a solution of $\mathrm{PPh}_{3}$ (1.89 g, $6.84 \mathrm{mmol}, 2$ equiv) in $\mathrm{MeCN}(27 \mathrm{~mL})$ at $\mathrm{rt}$ was added the residue from step 1 . The reaction mixture was stirred at $\mathrm{rt}$ for $20 \mathrm{~min}$ before a solution of $\mathrm{CBr}_{4}$ (2.84 g, $8.55 \mathrm{mmol}, 2.5$ equiv) in $\mathrm{MeCN}(11 \mathrm{~mL})$ was added. The reaction mixture was then stirred at $\mathrm{rt}$ for $20 \mathrm{~min}$ before adding a solution of $\mathrm{PPh}_{3}(472 \mathrm{mg}, 1.71 \mathrm{mmol}, 0.5$ equiv) in a 1:5.5 mixture of $\mathrm{MeCN} / \mathrm{MeOH}(45 \mathrm{~mL})$. The reaction mixture was then stirred for an additional $15 \mathrm{~min}$ before the solvent was removed under reduced pressure. The residue was subjected to flash chromatography (silica; PE/ EtOAc, 1:0 $\rightarrow$ 9:1). Collection of the first fraction $\left(R_{\mathrm{f}}=0.6\right.$; $\mathrm{PE} /$ EtOAc, 3:1) provided lactone $8(286 \mathrm{mg}, 20 \%)$ as a clear colorless oil. Collection of the appropriate fractions $\left(R_{\mathrm{f}}=0.4\right.$; $\mathrm{PE} / \mathrm{EtOAc}, 3: 1)$ provided nitrile 9 (741 $\mathrm{mg}, 52 \%)$ as a clear colorless oil. $[\alpha]_{\mathrm{D}}^{26.6} \circ \mathrm{C}-29$ (c 0.5 in $\left.\mathrm{CHCl}_{3}\right) ;{ }^{1} \mathrm{H}$ NMR $\left(\mathrm{CDCl}_{3}, 400 \mathrm{MHz}\right): \delta=7.37-7.24(\mathrm{~m}, 15 \mathrm{H}, \mathrm{Ar}-\mathrm{H}), 4.88(\mathrm{~d}, J$ $=11.5 \mathrm{~Hz}, 1 \mathrm{H}, \mathrm{CHPh}$ ), $4.82(\mathrm{~d}, J=11.2 \mathrm{~Hz}, 1 \mathrm{H}, \mathrm{CHPh}), 4.60$ (d, $J=11.2 \mathrm{~Hz}, 1 \mathrm{H}, \mathrm{CHPh}), 4.55(\mathrm{~d}, J=11.5 \mathrm{~Hz}, 1 \mathrm{H}, \mathrm{CHPh}$ ), $4.45(\mathrm{~d}, J=1.5 \mathrm{~Hz}, 2 \mathrm{H}, \mathrm{CHPh}), 4.43(\mathrm{~d}, J=6.6 \mathrm{~Hz}, 1 \mathrm{H}, \mathrm{H}-2)$, $4.11(\mathrm{~m}, 1 \mathrm{H}, \mathrm{H}-4), 3.88\left(\mathrm{dd}, J_{3,4}=2.9 \mathrm{~Hz}, J_{3,2}=6.6 \mathrm{~Hz}, 1 \mathrm{H}, \mathrm{H}-\right.$ 3), 3.45 (ddd in 1:2:2:1 ratio, $J_{5 \mathrm{a}, 4}=6.0 \mathrm{~Hz}, J=9.5 \mathrm{~Hz}, J_{5 \mathrm{~b}, 4}=$ $16.3 \mathrm{~Hz}, 2 \mathrm{H}, \mathrm{H}-5), 2.29$ (d, $J=7.2 \mathrm{~Hz}, 1 \mathrm{H}, \mathrm{OH}) ;{ }^{13} \mathrm{C}$ NMR $\left(\mathrm{CDCl}_{3}, 100 \mathrm{MHz}\right): \delta=137.7(\mathrm{Ar}), 137.3(\mathrm{Ar}), 135.7$ (Ar), 128.8-128.0 (Ar), $116.8(\mathrm{CN}), 78.1$ (C-3), $75.2(\mathrm{CH} 2), 73.4$ (CH2), 73.0 (CH2), 70.4 (C-5), 69.6 (C-4), 69.3 (C-2). IR $\left(\mathrm{ATR}, \mathrm{cm}^{-1}\right): 3470,3065,3032,2920,2870,1955,1882$, 1812, 1554, 1497, 1455, 1398, 1353, 1250, 1210, 1096, 1028, 1002, 913, 821, 738; HRMS (ESI): $m / z[\mathrm{M}+\mathrm{Na}]^{+}$calcd for $\mathrm{C}_{26} \mathrm{H}_{27} \mathrm{O}_{4} \mathrm{NNa}$, 440.1832; found, 440.1827. Data for 8: ${ }^{1} \mathrm{H}$ $\operatorname{NMR}\left(\mathrm{CDCl}_{3}, 400 \mathrm{MHz}\right): \delta=7.36-7.25(\mathrm{~m}, 15 \mathrm{H}), 5.05(\mathrm{~d}, J$ $=11.5 \mathrm{~Hz}, 1 \mathrm{H}), 4.60-4.50(\mathrm{~m}, 5 \mathrm{H}), 4.37(\mathrm{t}, J=7.1 \mathrm{~Hz}, 1 \mathrm{H})$, $3.77(\mathrm{dd}, J=2.9 \mathrm{~Hz}, J=10.8 \mathrm{~Hz}, 1 \mathrm{H}), 3.71(\mathrm{dd}, J=3.2 \mathrm{~Hz}, J=$ $10.8 \mathrm{~Hz}, 1 \mathrm{H}) .{ }^{13} \mathrm{C} \mathrm{NMR}\left(\mathrm{CDCl}_{3}, 100 \mathrm{MHz}\right): \delta=173.5,137.8$, 137.4, 137.2, 128.7-127.7, 79.5, 77.4 ( $2 \times \mathrm{C}), 73.8,72.8,72.7$, 67.3. The spectroscopic data for compound 8 were in full accord with the previously reported data. ${ }^{26}$

2,3,5-Tri-O-benzyl-4-(2-tert-butoxycarbonyl)hydrazinyl-4deoxy-D-arabinonitrile (10). Step 1: To a solution of alcohol 9 $(200 \mathrm{mg}, 0.48 \mathrm{mmol})$ in $\mathrm{DCM}(4 \mathrm{~mL})$ at $0{ }^{\circ} \mathrm{C}$ was added pyridine $(0.1 \mathrm{~mL}, 1.24 \mathrm{mmol}, 2.6$ equiv). The mixture was stirred for $10 \mathrm{~min}$ prior to dropwise addition of triflic anhydride $(0.1 \mathrm{~mL}, 0.60 \mathrm{mmol}, 1.25$ equiv). The reaction mixture was further stirred at $0{ }^{\circ} \mathrm{C}$ for $15 \mathrm{~min}$ before being diluted with DCM $(20 \mathrm{~mL})$, washed with cold $\mathrm{HCl}(10 \mathrm{~mL}, 1$ $\mathrm{M})$ and saturated aq $\mathrm{NaHCO}_{3}(12 \mathrm{~mL})$, dried over $\mathrm{MgSO}_{4}$, and filtered. The residue $\left(R_{\mathrm{f}}=0.71 ; \mathrm{PE} /\right.$ EtOAc, $\left.7: 3\right)$ was concentrated under reduced pressure and used directly in the following step. Step 2: To a solution of the triflate from step 1 in THF $(1.5 \mathrm{~mL})$ at $0{ }^{\circ} \mathrm{C}$ was added tert-butylcarbazate $(320$ $\mathrm{mg}, 2.42 \mathrm{mmol}, 5$ equiv). The reaction mixture was stirred at $\mathrm{rt}$ for $44 \mathrm{~h}$ before volatiles were removed under reduced pressure. The residue was subjected to flash column chromatography $(\mathrm{PE} /$ EtOAc, 95:5 $\rightarrow$ 9:1). Collection of the appropriate fractions $\left(R_{\mathrm{f}}=0.28 ; \mathrm{PE} / \mathrm{EtOAc}, 9: 1\right)$ provided hydrazide 10 $(138 \mathrm{mg}, 54 \%)$ as a clear white oil. ${ }^{1} \mathrm{H}$ NMR $\left(\mathrm{CDCl}_{3}, 400\right.$ $\mathrm{MHz}): \delta=7.36-7.28(\mathrm{~m}, 15 \mathrm{H}), 5.77$ (brs, $1 \mathrm{H}, \mathrm{NH}), 4.88$ (d, $J=11.5 \mathrm{~Hz}, 1 \mathrm{H}, \mathrm{CHPh}), 4.84(\mathrm{~d}, J=11.1 \mathrm{~Hz}, 1 \mathrm{H}, \mathrm{CHPh})$, $4.73\left(\mathrm{~d}, J_{2,3}=3.7 \mathrm{~Hz}, 1 \mathrm{H}, \mathrm{H}-2\right), 4.64(\mathrm{~d}, J=11.1 \mathrm{~Hz}, 1 \mathrm{H}$, $\mathrm{CHPh}), 4.57(\mathrm{~d}, J=11.5 \mathrm{~Hz}, 1 \mathrm{H}, \mathrm{CHPh}), 4.52(\mathrm{~d}, J=11.8 \mathrm{~Hz}$, $1 \mathrm{H}, \mathrm{CHPh}), 4.45(\mathrm{~d}, J=11.8 \mathrm{~Hz}, 1 \mathrm{H}, \mathrm{CHPh}), 3.82\left(\mathrm{dd}, J_{2,3}=\right.$ $\left.3.7 \mathrm{~Hz}, J_{3,4}=7.0 \mathrm{~Hz}, 1 \mathrm{H}, \mathrm{H}-3\right), 3.71\left(\mathrm{dd}, J_{5 \mathrm{a}, 4}=4.4 \mathrm{~Hz}, J_{5 \mathrm{a}, 5 \mathrm{~b}}=\right.$ $9.7 \mathrm{~Hz}, 1 \mathrm{H}, \mathrm{H}-5 \mathrm{a}), 3.60\left(\mathrm{dd}, J_{5 \mathrm{~b}, 4}=5.7 \mathrm{~Hz}, J_{5 \mathrm{~b}, 5 \mathrm{a}}=9.7 \mathrm{~Hz}, 1 \mathrm{H}\right.$, $\mathrm{H}-5 \mathrm{~b}$ ), 3.27 (ddd, $J_{4,5 \mathrm{a}}=4.4 \mathrm{~Hz}, J_{4,5 \mathrm{~b}}=5.7 \mathrm{~Hz}, J_{4,3}=7.0 \mathrm{~Hz}$, $1 \mathrm{H}, \mathrm{H}-4), 1.44(\mathrm{~s}, 9 \mathrm{H}) ;{ }^{13} \mathrm{C} \mathrm{NMR}\left(\mathrm{CDCl}_{3}, 100 \mathrm{MHz}\right): \delta=$ $156.7(\mathrm{C}=\mathrm{O}), 137.9(\mathrm{Ar}), 137.5(\mathrm{Ar}), 136.0(\mathrm{Ar}), 128.8-$ $128.0(\mathrm{Ar}), 117.8(\mathrm{CN}), 80.6\left(\mathrm{C}(\mathrm{CH} 3)_{3}\right), 78.1(\mathrm{C}-3), 74.9$ $\left(\mathrm{CH}_{2}\right), 73.5\left(\mathrm{CH}_{2}\right), 72.9\left(\mathrm{CH}_{2}\right), 68.3(\mathrm{C}-2), 67.8(\mathrm{C}-5), 60.5$ (C-4), $28.4\left(\mathrm{CH}_{3}\right)$; IR (ATR, cm $\left.{ }^{-1}\right): 3339,3014,2979,2929$, 2870, 1718, 1497, 1454, 1393, 1367, 1249, 1216, 1157, 1088, 1073, 1028; HRMS (ESI): $m / z[\mathrm{M}+\mathrm{H}]^{+}$calcd for $\mathrm{C}_{31} \mathrm{H}_{38} \mathrm{O}_{5} \mathrm{~N}_{3}, 532.2806$; found, 532.2802.

(2R,3R,4R)-1-Amino-3,4-bis(benzyloxy)-2-((benzyloxy)methyl)-5-iminopyrrolidin Hydrochloride (11). To a solution of nitrile 10 (140 mg, $0.26 \mathrm{mmol})$ in DCM $(10 \mathrm{~mL})$ at rt was added TFA $(2 \mathrm{~mL})$ dropwise. The reaction mixture was stirred at $\mathrm{rt}$ for $3 \mathrm{~h}$ before toluene was added, and the volatiles were removed in vacuo. The residue was then purified by flash column chromatography (DCM/MeOH $(0.1 \mathrm{M} \mathrm{HCl}), 94: 6)$. Collection of the appropriate fractions $\left(R_{\mathrm{f}}=0.35\right.$; DCM/ $\mathrm{MeOH}(0.1 \mathrm{M} \mathrm{HCl}), 9: 1)$ provided the title compound (98.3 $\mathrm{mg}, 88 \%)$ as a clear colorless oil. $[\alpha]_{\mathrm{D}}^{27.2} \circ \mathrm{C}-11$ (c 0.20 in $\mathrm{MeOH}$ ); ${ }^{1} \mathrm{H}$ NMR (MeOD, $\left.400 \mathrm{MHz}\right): \delta=7.34-7.25(\mathrm{~m}$, $15 \mathrm{H}, \mathrm{ArH}$ ), 4.82 (d, $\left.J_{4,3}=3.9 \mathrm{~Hz}, 1 \mathrm{H}, \mathrm{H}-4\right), 4.73$ (d, $J=11.5$ $\mathrm{Hz}, 1 \mathrm{H}, \mathrm{CHPh}$ ), 4.63 (d, $J=11.5 \mathrm{~Hz}, 1 \mathrm{H}, \mathrm{CHPh}), 5.59$ (d, $J=$ $11.8 \mathrm{~Hz}, 1 \mathrm{H}, \mathrm{CHPh}$ ), 4.48 (bs, 2H, CHPh), 4.47 (d, $J=11.8$ $\mathrm{Hz}, 1 \mathrm{H}, \mathrm{CHPh}), 4.25(\mathrm{t}, J=3.9 \mathrm{~Hz}, 1 \mathrm{H}, \mathrm{H}-3), 3.96(\mathrm{~m}, 1 \mathrm{H}, \mathrm{H}-$ 2), $3.89\left(\mathrm{dd}, J_{\mathrm{CHaOH}, 2}=3.4 \mathrm{~Hz}, J_{\mathrm{CHaOH}, \mathrm{CHbOH}}=10.9 \mathrm{~Hz}, 1 \mathrm{H}\right.$, $\mathrm{CHaOH}), 3.63\left(\mathrm{dd}, J_{\mathrm{CHbOH}, 2}=3.2 \mathrm{~Hz}, J_{\mathrm{CHbOH}, \mathrm{CHaOH}}=10.9\right.$ $\mathrm{Hz}, 1 \mathrm{H}, \mathrm{CHbOH}) ;{ }^{13} \mathrm{C}$ NMR (MeOD, $\left.100 \mathrm{MHz}\right): \delta=166.7$ $(\mathrm{C}=\mathrm{N}), 138.9$ (Ar), $138.4(\mathrm{Ar}), 138.1(\mathrm{Ar}), 129.6-129.1$ (Ar), 82.3 (C-4), $79.6(\mathrm{C}-3), 74.2\left(\mathrm{CH}_{2}\right), 74.0\left(\mathrm{CH}_{2}\right)$, 73.3 $\left(\mathrm{CH}_{2}\right), 71.0(\mathrm{C}-2), 66.3\left(\mathrm{CH}_{2} \mathrm{OH}\right)$; IR $\left(\mathrm{ATR}, \mathrm{cm}^{-1}\right)$ : $3029,2929,2110,1953,1882,1811,1702,1624,1495,1453$, 1362, 1261, 1209, 1121, 1099, 1063, 1028, 971, 915; HRMS (ESI): $m / z[\mathrm{M}+\mathrm{H}]^{+}$calcd for $\mathrm{C}_{26} \mathrm{H}_{30} \mathrm{O}_{3} \mathrm{~N}_{3}, 432.2282$; found, 432.2276 .

(2R,3R,4R)-1-Amino-3,4-dihydroxy-2-(hydroxymethyl)-5iminopyrrolidine Hydrochloride (4CI). A degassed suspension of per-O-benzylated hydrazide imide $11(98 \mathrm{mg}, 0.23 \mathrm{mmol})$ and $\mathrm{Pd} / \mathrm{C}(280 \mathrm{mg})$ in EtOH/TFA $(10 \mathrm{~mL}, 9: 1)$ was hydrogenated at $1 \mathrm{~atm}$ at $\mathrm{rt}$ for $19 \mathrm{~h}$. The reaction mixture was then filtered through Celite and washed with EtOH before the filtrate was concentrated in vacuo. The residue was dissolved in methanolic $\mathrm{HCl}(0.5 \mathrm{M})$ and evaporated to dryness to afford the $\mathrm{HCl}$ salt. The salt residue was purified by flash column chromatography $\left(\mathrm{MeCN} / \mathrm{H}_{2} \mathrm{O}, 92: 8\right)$. Collection of the appropriate fractions $\left(R_{\mathrm{f}}=0.42 ; \mathrm{MeCN} / \mathrm{H}_{2} \mathrm{O}(0.1 \mathrm{M} \mathrm{HCl})\right.$, $85: 15)$ provided pyrrolidine $4 \mathrm{Cl}(40 \mathrm{mg}, 90 \%)$ as a yellow solid; mp 156.0-156.2 ${ }^{\circ} \mathrm{C}$ (decomposes); $[\alpha]_{\mathrm{D}}^{27.2 \circ \mathrm{C}}-5.7(c$ 0.35 in $\mathrm{MeOH}) ;{ }^{1} \mathrm{H}$ NMR $\left(\mathrm{D}_{2} \mathrm{O}, 400 \mathrm{MHz}\right): \delta=4.83\left(\mathrm{~d}, J_{4,3}=\right.$ $7.0 \mathrm{~Hz}, 1 \mathrm{H}, \mathrm{H}-4), 4.27$ (t, $J=7.0 \mathrm{~Hz}, 1 \mathrm{H}, \mathrm{H}-3), 4.13$ (dd, $\left.J_{\mathrm{CHaOH}, 2}=2.6 \mathrm{~Hz}, J_{\mathrm{CHaOH}, \mathrm{CHbOH}}=13.3 \mathrm{~Hz}, 1 \mathrm{H}, \mathrm{CHaOH}\right), 3.87$ $\left(\right.$ dd, $\left.J_{\mathrm{CHbOH}, 2}=2.5 \mathrm{~Hz}, J_{\mathrm{CHbOH}, \mathrm{CHaOH}}=13.3 \mathrm{~Hz}, 1 \mathrm{H}, \mathrm{H}-6 \mathrm{~b}\right)$, 3.72 (app. dt, $\left.J_{2, \mathrm{CHOH}}=2.5 \mathrm{~Hz}, J_{2,3}=7.0 \mathrm{~Hz}, 1 \mathrm{H}, \mathrm{H}-2\right) ;{ }^{13} \mathrm{C}$ NMR ( $\left.\mathrm{D}_{2} \mathrm{O}, 100 \mathrm{MHz}\right): \delta=167.4(\mathrm{C}=\mathrm{N}), 74.1(\mathrm{C}-4), 72.7$ (C-3), 68.7 (C-2), $55.5\left(\mathrm{CH}_{2} \mathrm{OH}\right)$. IR (ATR, cm $\left.{ }^{-1}\right): 3369$, 2125, 1724, 1624, 1205, 1109, $1063 \mathrm{~cm}^{-1}$; HRMS (ESI): $\mathrm{m} / z$ $[\mathrm{M}+\mathrm{H}]^{+}$calcd for $\mathrm{C}_{5} \mathrm{H}_{12} \mathrm{O}_{3} \mathrm{~N}_{3}, 162.0873$; found, 162.0871 .

(2R,3R,4R)-1-(Ethylamino)-3,4-dihydroxy-2-(hydroxymethyl)-5-iminopyrrolidine Hydrochloride (5Cl). A degassed 
suspension of pyrrolidine 11 (95 mg, $0.20 \mathrm{mmol}$ ) and $\mathrm{Pd} / \mathrm{C}$ $(235 \mathrm{mg})$ in EtOH/TFA ( $2 \mathrm{~mL}, 9: 1)$ was hydrogenated at 1 atm at rt for $48 \mathrm{~h}$. The reaction mixture was then filtered through Celite and washed with EtOH before the filtrate was concentrated in vacuo. The residue was dissolved in methanolic $\mathrm{HCl}(0.5 \mathrm{M})$ and evaporated to dryness to afford the $\mathrm{HCl}$ salt. The salt residue was purified by flash column chromatography $\left(\mathrm{MeCN} / \mathrm{H}_{2} \mathrm{O}, 88: 12\right)$. Collection of the appropriate fractions $\left(R_{\mathrm{f}}=0.44 ; \mathrm{MeCN} / \mathrm{H}_{2} \mathrm{O}, 9: 1\right)$ provided the title compound ( $39 \mathrm{mg}, 85 \%$ ) as a yellow solid; mp 130.2$130.4{ }^{\circ} \mathrm{C}$ (decomposes); $[\alpha]_{\mathrm{D}}^{25.2} \mathrm{oC}^{\circ} 12.0$ (c 0.17 in $\left.\mathrm{MeOH}\right)$ ${ }^{1} \mathrm{H}$ NMR $\left(\mathrm{D}_{2} \mathrm{O}, 400 \mathrm{MHz}\right): \delta=4.90\left(\mathrm{~d}, J_{4,3}=6.9 \mathrm{~Hz}, 1 \mathrm{H}, \mathrm{H}-\right.$ 4), 4.31 (app. $\mathrm{t}, J=6.8 \mathrm{~Hz}, 1 \mathrm{H}, \mathrm{H}-3$ ), 4.07 (dd, $J_{\mathrm{CHaOH}, 6 \mathrm{~b}}=$ $\left.13.0 \mathrm{~Hz}, J_{\mathrm{CHbOH}, 2}=2.6 \mathrm{~Hz}, 1 \mathrm{H}, \mathrm{CHaOH}\right), 4.03\left(\mathrm{dt}, J_{2,3}=6.7\right.$ $\left.\mathrm{Hz}, J_{2, \mathrm{CHbOH}}=2.7 \mathrm{~Hz}, J_{2, \mathrm{CHaOH}}=2.6 \mathrm{~Hz}, 1 \mathrm{H}, \mathrm{H}-2\right), 3.90(\mathrm{dd}$, $\left.J_{\mathrm{CHbOH}, \mathrm{CHaOH}}=13.0 \mathrm{~Hz}, J_{\mathrm{CHbOH}, 2}=2.7 \mathrm{~Hz}, 1 \mathrm{H}, \mathrm{CHbOH}\right), 3.04$ $\left(\mathrm{dq}, J_{1^{\prime} \mathrm{a}, 1^{\prime} \mathrm{b}}=11.7 \mathrm{~Hz}, J_{1^{\prime} \mathrm{a}, 2^{\prime}}=7.3 \mathrm{~Hz}, 1 \mathrm{H}, \mathrm{H}-1^{\prime} \mathrm{a}\right), 2.91(\mathrm{dq}$, $J_{1^{\prime} \mathrm{b}, 1^{\prime} \mathrm{a}}=11.7 \mathrm{~Hz}, J_{1^{\prime} \mathrm{b}, 2^{\prime}}=7.1 \mathrm{~Hz}, 1 \mathrm{H}, \mathrm{H}-1^{\prime} \mathrm{b}$ ), 1.09 (app. t, $J=$ $\left.7.2 \mathrm{~Hz}, 3 \mathrm{H}, \mathrm{H}-2^{\prime}\right) ;{ }^{13} \mathrm{C}$ NMR $\left(\mathrm{D}_{2} \mathrm{O}, 100 \mathrm{MHz}\right): \delta=167.9$ $(\mathrm{C}=\mathrm{N}), 73.9(\mathrm{C}-4), 73.0(\mathrm{C}-3), 64.8(\mathrm{C}-2), 56.0\left(\mathrm{CH}_{2} \mathrm{OH}\right)$, 42.0 (C-7), 11.8 (C-8); IR (ATR, cm ${ }^{-1}$ ): 3215, 2977, 2934, 2878, 2110, 1702, 1637, 1454, 1383, 1332, 1276, 1201, 1103, 1063, 905; HRMS (ESI): $m / z[\mathrm{M}+\mathrm{H}]^{+}$calcd for $\mathrm{C}_{7} \mathrm{H}_{16} \mathrm{O}_{3} \mathrm{~N}_{3}$, 190.1186; found, 190.1184 .

(3S,4R,5R)-1-Amino-3,4-dihydroxy-5-(hydroxymethyl)-2pyrrolidinone Hydrochloride $(6 \mathrm{HCl})$. A solution of pyrrolidine $4 \mathrm{Cl}(8 \mathrm{mg}, 0.04 \mathrm{mmol})$ in $\mathrm{MeOH}(0.05 \mathrm{M} \mathrm{HCl}, 1 \mathrm{~mL})$ was subjected to microwave radiation $\left(150{ }^{\circ} \mathrm{C}\right)$ for $90 \mathrm{~min}$. The reaction mixture was then cooled to ambient temperature before volatiles were removed by reduced pressure. The residue was evaporated to dryness to afford the $\mathrm{HCl}$ salt. The salt residue was subjected to gravity column chromatography $\left(\mathrm{MeCN} / \mathrm{H}_{2} \mathrm{O}\right.$, 98:2). Collection of the appropriate fractions $\left(R_{\mathrm{f}}=0.41 ; \mathrm{MeCN} / \mathrm{H}_{2} \mathrm{O}, 85: 15\right)$ provided hydrazide amide $6 \mathrm{HCl}(4.7 \mathrm{mg}, 60 \%)$ as a white wax. $[\alpha]_{\mathrm{D}}^{25.5} \circ \mathrm{C}-5.1$ (c $0.39 \mathrm{in}$ $\mathrm{MeOH}) ;{ }^{1} \mathrm{H}$ NMR $\left(\mathrm{D}_{2} \mathrm{O}, 400 \mathrm{MHz}\right): \delta=4.31\left(\mathrm{~d}, J_{4,3}=7.1\right.$ $\mathrm{Hz}, 1 \mathrm{H}, \mathrm{H}-3), 4.10$ (t, $J=7.1 \mathrm{~Hz}, 1 \mathrm{H}, \mathrm{H}-4), 4.05$ (dd, $J_{\mathrm{CHaOH}, 2}$ $\left.=2.7 \mathrm{~Hz}, J_{\mathrm{CHaOH}, \mathrm{CHbOH}}=12.9 \mathrm{~Hz}, 1 \mathrm{H}, \mathrm{CHaOH}\right), 3.79(\mathrm{dd}$, $\left.J_{\mathrm{CHbOH}, 2}=2.5 \mathrm{~Hz}, J_{\mathrm{CHbOH}, \mathrm{CHaOH}}=12.9 \mathrm{~Hz}, 1 \mathrm{H}, \mathrm{CHbOH}\right), 3.47$ $(\mathrm{m}, 1 \mathrm{H}, \mathrm{H}-5) ;{ }^{13} \mathrm{C}$ NMR $\left(\mathrm{D}_{2} \mathrm{O}, 100 \mathrm{MHz}\right): \delta=172.5(\mathrm{C}=$ O), 75.2 (C-3), 72.3 (C-4), 65.3 (C-5), $57.2\left(\mathrm{CH}_{2} \mathrm{OH}\right)$; IR $\left(\mathrm{ATR}, \mathrm{cm}^{-1}\right): 3295,2926,2855,2358,1699,1455,1349$, 1261, 1200, 1095, 909. LRMS (ESI): $m / z[\mathrm{M}+\mathrm{H}]^{+}$calcd for $\mathrm{C}_{5} \mathrm{H}_{11} \mathrm{O}_{4} \mathrm{~N}_{2}$, 163.0719; found, 163.0721.

2,3,5-Tri-O-benzyl-4-(1-N-benzyl-(2-tert-butoxycarbonyl)hydrazinyl)-4-deoxy-D-arabinonitrile (13). To a solution of compound 10 (104 mg, $0.20 \mathrm{mmol}$ ) in DCE was added $\mathrm{Na}(\mathrm{OAc})_{3} \mathrm{BH}$ (116 mg, 2.7 equiv) followed by benzaldehyde ( $0.04 \mathrm{~mL}, 2.0$ equiv) and $\mathrm{AcOH}(0.07 \mathrm{~mL}, 6.2$ equiv). The reaction mixture was stirred at $\mathrm{rt}$ for $18 \mathrm{~h}$. The reaction mixture was then quenched with saturated aq $\mathrm{NaHCO}_{3}(5 \mathrm{~mL})$, and EtOAc $(10 \mathrm{~mL})$ was added. The two phases were separated, and the aq phase was extracted with EtOAc $(2 \times 10 \mathrm{~mL})$. The combined organic fractions were evaporated to dryness in vacuo. Excess of benzaldehyde was removed under vacuum at $60{ }^{\circ} \mathrm{C}$ for $1 \mathrm{~h}$. The residue was purified by flash column chromatography (PE/EtOAc, 9:1). Collection of the appropriate fractions $\left(R_{\mathrm{f}}=0.25 ; \mathrm{PE} / \mathrm{EtOAc}, 9: 1\right)$ provided compound 13 (89 $\mathrm{mg}, 73 \%$ ) as a light-yellow oil. ${ }^{1} \mathrm{H}$ NMR $\left(\mathrm{CDCl}_{3}, 400 \mathrm{MHz}\right): \delta=7.41-6.96(\mathrm{~m}, 20 \mathrm{H}, \mathrm{ArH}), 6.28$ and 5.84 (br.s, 1.4:1, 1H, NH), 5.52 and 5.22 (br.s, 1.5:1, 1H, H2), $4.98(\mathrm{~d}, J=10.9 \mathrm{~Hz}, 1 \mathrm{H}, \mathrm{CHPh}), 4.84(\mathrm{~d}, J=10.3 \mathrm{~Hz}, 1 \mathrm{H}$, CHPh), 4.60 (d, J = 10.8 Hz, 1H, CHPh), 4.58 (d, $J=10.3 \mathrm{~Hz}$,
$1 \mathrm{H}, \mathrm{CHPh}), 4.49$ (d, $J=11.2 \mathrm{~Hz}, 2 \mathrm{H}, 2 \mathrm{CHPh}), 4.00-3.68(\mathrm{~m}$, $5 \mathrm{H}, 2 \mathrm{CHPh}, \mathrm{H}-5 \mathrm{a}, \mathrm{H}-5 \mathrm{~b}, \mathrm{H}-3$ ), 3.34 (brs, 1H, H-4), 1.32$1.24(\mathrm{~m}, 9 \mathrm{H}) ;{ }^{13} \mathrm{C} \mathrm{NMR}\left(\mathrm{CDCl}_{3}, 100 \mathrm{MHz}\right): \delta=155.9(\mathrm{C}=$ O), 137.8-136.1 (Ar), 130.0-127.5 (Ar), 118.9-118.6 (CN), 80.8 and $80.0(\mathrm{C}), 78.4(\mathrm{C}-3), 75.2$ and $74.9\left(\mathrm{CH}_{2}\right), 73.8$ and $73.6\left(\mathrm{CH}_{2}\right), 73.2$ and $72.8\left(\mathrm{CH}_{2}\right), 67.6$ and $66.7(\mathrm{C}-2), 67.0$ $(\mathrm{CH} 2), 63.6$ and 61.9 (C-5), 61.6 and 60.7 (C-4), 28.3 and $28.1\left(\mathrm{CH}_{3}\right)$; IR $\left(\mathrm{ATR}, \mathrm{cm}^{-1}\right): 3355,3031,2925,2866,1950$, $1725,1706,1496,1454,1392,1243,1160,1124,1072,1027$, 913; HRMS (ESI): $m / z[\mathrm{M}+\mathrm{Na}]^{+}$calcd for $\mathrm{C}_{38} \mathrm{H}_{43} \mathrm{O}_{5} \mathrm{~N}_{3} \mathrm{Na}$, 644.3095; found, 644.3088 .

Glycosidase Inhibition Assays. Inhibition assays for glycosidases were accomplished using the methodology reported by Bols and co-workers. ${ }^{32}$ The percentage of inhibition was measured by preparing two $1.2 \mathrm{~mL}$ samples in PS cuvettes containing $0.1 \mathrm{M}$ phosphate buffer $(\mathrm{pH} 6.8$ or 5.6 for mannosidases) and the corresponding $o$ - or $p$-nitrophenylglycopyranoside at a concentration equal to the expected value of $K_{\mathrm{M}}:[S]=0.25 \mathrm{mM}$ for $\alpha$-glucosidase, $4.0 \mathrm{mM}$ for $\beta$ glucosidase; $0.60 \mathrm{mM}$ for $\alpha$-galactosidase, $0.51 \mathrm{mM}$ for $\beta$ galactosidase (E. coli), $1.5 \mathrm{mM}$ for $\beta$-galactosidase (A. oryzae), $0.90 \mathrm{mM}$ for $\alpha$-mannosidase, and $0.58 \mathrm{mM}$ for $\beta$-mannosidase. DMSO (control) or inhibitor solution (DMSO) plus water was added up to a constant volume of $1.14 \mathrm{~mL}$. Screenings were conducted using a $100 \mu \mathrm{M}$ final inhibitor concentration.

Reactions were started by adding $60 \mu \mathrm{L}$ of properly diluted enzyme solution at $25 \pm 0.1{ }^{\circ} \mathrm{C}$ or $35 \pm 0.1{ }^{\circ} \mathrm{C}$ (for mannosidases), and the formation of the corresponding $o$ - or $p$-nitrophenolate was monitored for $125 \mathrm{~s}$ by measuring the increase in absorbance at $400 \mathrm{~nm}$ (glucosidases and $\alpha$ galactosidase) or $420 \mathrm{~nm}$ ( $\beta$-galactosidases) for $125 \mathrm{~s}$. For $\alpha$ and $\beta$-mannosidases, an aliquot $(200 \mu \mathrm{L})$ was taken every $60 \mathrm{~s}$ and added to a $1 \mathrm{M} \mathrm{Na}_{2} \mathrm{CO}_{3}$ solution $(1.8 \mathrm{~mL})$, and the absorbance was measured at $400 \mathrm{~nm}$ over a period of $4 \mathrm{~min}$.

Initial rates (slopes of the plots Abs vs $t$ ) were used for calculating \% $I$, according to the following expression:

$$
\% \text { inhibition }=\frac{v_{0}-v}{v_{0}} \times 100
$$

where $v_{0}$ is the reaction rate for the enzyme solution and $v$ is the reaction rate for the reactions incorporating an inhibitor.

DMSO concentration was maintained at $5 \%(\mathrm{v} / \mathrm{v})$ of the total assay mixture for glycosidases.

The inhibitory constants $\left(K_{\mathrm{i}}\right)$ were determined using five different substrate concentrations, ranging from 0.25 to $4.0 K_{\mathrm{M}}$ at a fixed inhibitor concentration (two to three different inhibitor concentrations). The mode of inhibition was determined using the Cornish-Bowden method, ${ }^{33}$ which involves the use of two different plots: $1 / v$ vs $[I]$ (Dixon plot) and $[S] / v$ vs $[I]$. For the calculation of kinetic parameters $\left(K_{\mathrm{M}}, V_{\max }\right)$, a nonlinear regression analysis (least-squares fit) was used.

Compounds $4 \mathrm{Cl}$ and $5 \mathrm{Cl}$ turned out to be competitive inhibitors (binding only to the free enzyme), and the corresponding inhibition constants $\left(K_{\mathrm{i}}\right)$ were calculated using the following equation:

$$
K_{\mathrm{ia}}=\frac{[I]}{\frac{K_{\mathrm{M} \mathrm{app}}}{K_{\mathrm{M}}}-1}
$$

Computational Details. Geometries of the investigated molecular systems were optimized with Schlegel's gradient optimization algorithm. ${ }^{34}$ Subsequent to geometry optimiza- 
tion, the second derivative Hessian matrices were evaluated analytically for the located stationary points on the explored potential energy surfaces (PESs). The absence of negative eigenvalues of the Hessians (and consequently, imaginary harmonic vibrational frequencies) indicated that true minima have been located.

Throughout the study, the hybrid HF-DFT approach was implemented, using the combination of three-parameter adiabatic connection exchange functional constructed by Becke (B3) ${ }^{35}$ with the Lee-Yang-Parr correlation functional (LYP; ${ }^{36}$ B3-LYP). The Pople-style triple-zeta quality 6-311+ $+\mathrm{G}(d, p)$ basis set was used for orbital expansion. Numerical integration was performed using a pruned "ultrafine" (99,590) grid, constituted by 99 radial shells and 590 angular points per shell.

Charge distribution for the structure corresponding to the located minima on the studied PESs was investigated employing a variety of methods for computation/assignment of atomic charges. Aside from the widely used Mulliken partitioning scheme and the Weinhold's natural population analysis, ${ }^{37}$ also several electrostatic potential-based (ESP) schemes were employed. ${ }^{38-41}$ The ESP schemes are based on computation of molecular ESP from the DFT density (which is an exact procedure) followed by assignment of charges to atomic centers within the molecule, such as reproducing the exactly computed ESP at series of chosen points. The second segment of the overall task is a fitting procedure. As the ESP fit does not lead to a unique solution of the problem (neither does any of the algorithms for charge assignments), we have used many different algorithms for choosing the set of points for fitting the charges ( $\mathrm{MK}, \mathrm{CHelp}$, CHelpG, etc.; see the results in Table 2 within the main text). This was done in order to get a wider overview of the performances of different methods. We have also focused on trends throughout the series of investigated compounds instead of the absolute values of the charges.

\section{ASSOCIATED CONTENT}

\section{SI Supporting Information}

The Supporting Information is available free of charge at https://pubs.acs.org/doi/10.1021/acsomega.0c02466.

${ }^{1} \mathrm{H}$ NMR, ${ }^{13} \mathrm{C} \mathrm{NMR}$, and IR spectra of synthesized compounds (PDF)

\section{AUTHOR INFORMATION}

\section{Corresponding Authors}

Emil Lindbäck - Department of Chemistry, Bioscience and Environmental Engineering, Faculty of Science and Technology, University of Stavanger, 4036 Stavanger, Norway;

Email: emil.lindback@uis.no

Magne O. Sydnes - Department of Chemistry, Bioscience and Environmental Engineering, Faculty of Science and Technology, University of Stavanger, 4036 Stavanger, Norway; (1) orcid.org/0000-0001-9413-6969;

Email: magne.o.sydnes@uis.no

\section{Authors}

Marianne B. Haarr - Department of Chemistry, Bioscience and Environmental Engineering, Faculty of Science and Technology, University of Stavanger, 4036 Stavanger, Norway

Óscar Lopéz - Departamento de Quimica Orgánica, Facultad De Quimica, Universidad de Sevilla, 41012 Seville, Spain
Ljupcho Pejov - Department of Chemistry, Bioscience and Environmental Engineering, Faculty of Science and Technology, University of Stavanger, 4036 Stavanger, Norway

José G. Fernández-Bolaños - Departamento de Quimica Orgánica, Facultad De Quimica, Universidad de Sevilla, 41012 Seville, Spain; O orcid.org/0000-0003-1499-0650

Complete contact information is available at:

https://pubs.acs.org/10.1021/acsomega.0c02466

\section{Notes}

The authors declare no competing financial interest.

\section{ACKNOWLEDGMENTS}

We thank the ToppForsk program at the University of Stavanger, Dirección General de Investigación of Spain (CTQ2016-78703-P), Junta de Andalucia (FQM134), and FEDER (501100008530) for financial support. COST Action Multi-target paradigm for innovative ligand identification in the drug discovery process (MuTaLig) (CA15135) is also acknowledged (Ó.L. and M.O.S).

\section{REFERENCES}

(1) Gloster, T. M.; Davies, G. J. Glycosidase inhibition: assessing mimicry of the transition state. Org. Biomol. Chem. 2010, 8, 305-320.

(2) Asano, N. Glycosidase inhibitors: update and perspectives on practical use. Glycobiology 2003, 13, 93R-104R.

(3) Stütz, A. E.; Wrodnigg, T. M. Imino sugars and glycosyl hydrolases. Adv. Carbohydr. Chem. Biochem. 2011, 66, 187-298.

(4) Sugimoto, S.; Nakajima, H.; Kosaka, K.; Hosoi, H. Review: Miglitol has potential as a therapeutic drug against obesity. Nutr. Metab. 2015, 12, 51.

(5) Stirnemann, J.; Belmatoug, N.; Camou, F.; Serratrice, C.; Froissart, R.; Caillaud, C.; Levade, T.; Astudillo, L.; Serratrice, J.; Brassier, A.; Rose, C.; Billette de Villemeur, T.; Berger, M. A review of Gaucher disease pathophysiology, clinical presentation and treatments. Int. J. Mol. Sci. 2017, 18, E441.

(6) Sunder-Plassmann, G.; Schiffmann, R.; Nicholls, K. Migalastat for the treatment of Fabry disease. Expert Opin. Orphan Drugs 2018, 6, 301-309.

(7) Asano, N.; Nash, R. J.; Molyneux, R. J.; Fleet, G. W. J. Sugarmimic glycosidase inhibitors: natural occurrence, biological activity and prospects for therapeutic application. Tetrahedron: Asymmetry 2000, 11, 1645-1680.

(8) Kiappes, J. L.; Hill, M. L.; Alonzi, D. S.; Miller, J. L.; Iwaki, R.; Sayce, A. C.; Caputo, A. T.; Kato, A.; Zitzmann, N. ToP-DNJ, a selective inhibitor of endoplasmic reticulum $\alpha$-glucosidase II exhibiting antiflaviviral activity. ACS Chem. Biol. 2017, 13, 60-65.

(9) (a) Asano, N. Naturally occurring iminosugars and related compounds: structure, distribution, and biological activity. Curr. Top. Med. Chem. 2003, 3, 471-484. (b) Dehoux-Baudoin, C.; Génisson, Y. $C$-Branched Imino sugars: Synthesis and biological relevance. Eur. J. Org. Chem. 2019, 4765-4777.

(10) Heightman, T. D.; Vasella, A. T. Recent insights into inhibition, structure, and mechanism of configuration-retaining glycosidases. Angew. Chem. Int. Ed. 1999, 38, 750-770.

(11) (a) Lillelund, V. H.; Jensen, H. H.; Liang, X.; Bols, M. Recent developments of transition-state analogue glycosidase inhibitors of non-natural product origin. Chem. Rev. 2002, 102, 515-554. (b) Stütz, A. E.; Wrodnigg, T. M. Positive attitude, shape, flexibility, added-value accessories or "just being different": how to attract a glycosidase. Carbohydr. Chem. 2013, 39, 120-149.

(12) Jespersen, T. M.; Dong, W.; Sierks, M. R.; Skrydstrup, T.; Lundt, I.; Bols, M. Isofagomine, a potent, new glycosidase inhibitor. Angew. Chem., Int. Ed. Engl. 1994, 33, 1778-1779.

(13) Varrot, A.; Tarling, C. A.; Macdonald, J. M.; Stick, R. V.; Zechel, D. L.; Withers, S. G.; Davies, G. J. Direct observation of the 
protonation state of an imino sugar glycosidase inhibitor upon binding. J. Am. Chem. Soc. 2003, 125, 7496-7497.

(14) Tong, M. K.; Papandreou, G.; Ganem, B. Potent, broadspectrum inhibition of glycosidases by an amidine derivative of Dglucose. J. Am. Chem. Soc. 1990, 112, 6137-6139.

(15) Whitworth, G. E.; Macauley, M. S.; Stubbs, K. A.; Dennis, R. J.; Taylor, E. J.; Davies, G. J.; Greig, I. R.; Vocadlo, D. J. Analysis of PUGNAc and NAG-thiazoline as Transition State Analogues for Human O-GlcNAcase: Mechanistic and Structural Insights into Inhibitor Selectivity and Transition State Poise. J. Am. Chem. Soc. 2007, 129, 635-644.

(16) Lindbäck, E.; López, Ó.; Fernández-Bolaños, J. G.; Sauer, S. P. A.; Bols, M. An isofagomine analogue with an amidine at the pseudoanomeric position. Org. Lett. 2011, 13, 2908-2911.

(17) Gnanesh Kumar, B. S.; Pohlentz, G.; Schulte, M.; Mormann, M.; Siva Kumar, N. Jack bean $\alpha$-mannosidase: Amino acid sequencing and $\mathrm{N}$-glycosylation analysis of a valuable glycomics tool. Glycobiology 2014, 24, 252-261.

(18) (a) Bols, M.; López, Ó.; Ortega-Caballero, F. Glycosidase inhibitors: structure, activity, synthesis, and medical relevance. in Comprehensive Glycoscience-From Chemistry to Systems Biology; Kamerling, J. P. (Ed), Elsevier: 2007, pp. 815-884. (b) López, O.; Merino-Montiel, P.; Martos, S.; González-Benjumea, A. Glycosidase inhibitors: versatile tools in glycobiology. in Carbohdrate ChemistryChemical and Biological Approaches; Rauter, A. P.; Lindhorst, T. K. (Eds), RSC: 2012, Vol. 38, pp. 215-262.

(19) Suzuki, K.; Nakahara, T.; Kanie, O. 3,4-Dihydroxypyrrolidine as glycosidase inhibitor. Curr. Top. Med. Chem. 2009, 9, 34-57.

(20) (a) Liu, K. K.-C.; Kajimoto, T.; Chen, L.; Zhong, Z.; Ichikawa, Y.; Wong, C.-H. Use of dihydroxyacetone phosphate-dependent aldolases in the synthesis of deoxy aza sugars. J. Org. Chem. 1991, 56, 6280-6289. (b) Wong, C.-H.; Provencher, L.; Porco, J. A.; Jung, S.H.; Wang, Y.-F.; Chen, L.; Wang, R.; Steensma, D. H. Synthesis and evaluation of homoaza sugars as glycosidase inhibitors. J. Org. Chem. 1995, 60, 1492-1501.

(21) Garrabou, X.; Gómez, L.; Joglar, J.; Gil, S.; Parella, T.; Bujons, J.; Clapés, P. Structure-Guided Minimalist Redesign of the L-fuculose1-phosphate aldolase active site: Expedient synthesis of novel polyhydroxylated pyrrolizidines and their inhibitory properties against glycosidases and intestinal disaccharidases. Chem. - Eur. J. 2010, 16, 10691-10706.

(22) Mena-Barragán, T.; García-Moreno, M. I.; Nanba, E.; Higaki, K.; Concia, A. L.; Clapés, P.; García Fernández, J. M.; Ortiz Mellet, C. Inhibitor versus chaperone behaviour of d-fagomine, $D A B$ and $\mathrm{LAB}$ sp2-iminosugar conjugates against glycosidases: A structure-activity relationship study in Gaucher fibroblasts. Eur. J. Med. Chem. 2016, $121,880-891$.

(23) Lindbäck, E.; Lopéz, Ó.; Tobiesen, Å.; Fernández-Bolaños, J. G.; Sydnes, M. O. Sugar hydrazide imides: a new family of glycosidase inhibitors. Org. Biomol. Chem. 2017, 15, 8709-8712.

(24) Santos Evangelista, T. C.; Lopéz, Ó.; Sydnes, M. O.; Fernández-Bolaños, J. G.; Baptista Ferreira, S.; Lindbäck, E. Bicyclic 1-azafagomine derivatives: synthesis and glycosidase inhibitory testing. Synthesis 2019, 51, 4066-4077.

(25) Ermert, P.; Vasella, A. Synthesis of a glucose-derived tetrazole as a new $\beta$-glucosidase inhibitor: A new synthesis of 1-deoxynojirimycin. Helv. Chim. Acta 1991, 74, 2043-2053.

(26) Meng, Q.; Hesse, M. A new synthesis of (2S,3R,4R)-2(hydroxymethyl)pyrrolidine-3,4-diol. Helv. Chim. Acta 1991, 74, 445-450.

(27) Rasmussen, T. S.; Koldsø, H.; Nakagawa, S.; Kato, A.; Schiøtt, B.; Jensen, H. H. Synthesis of uronic-noeurostegine -a potent bacterial $\beta$-glucuronidase inhibitor. Org. Biomol. Chem. 2011, 9, 7807-7813.

(28) Sydnes, M. O.; Isobe, M. One-pot reductive monoalkylation of nitro aryls with hydrogen over Pd/C. Tetrahedron Lett. 2008, 49, 1199-1202.

(29) Esaki, H.; Ohtaki, R.; Maegawa, T.; Monguchi, Y.; Sajiki, H. Novel Pd/C-catalyzed redox reactions between aliphatic secondary alcohols and ketones under hydrogenation conditions: application to
H-D exchange reaction and the mechanistic study. J. Org. Chem. 2007, $72,2143-2150$.

(30) Franconetti, A.; López, Ó.; Fernandez-Bolanos, J. G. Carbohydrates: potential sweet tools against cancer. Curr. Med. Chem. 2020, 27, 1206-1242.

(31) Ganem, B.; Papandreou, G. Mimicking the glucosidase transition state: shape/charge considerations. J. Am. Chem. Soc. 1991, 113, 8984-8985.

(32) Bols, M.; Hazell, R. G.; Thomsen, I. B. 1-Azafagomine: A hydroxyhexahydropyridazine that potently inhibits enzymatic glycoside cleavage. Chem. - Eur. J. 1997, 3, 940-947.

(33) Cornish-Bowden, A. A simple graphical method for determining the inhibition constants of mixed, uncompetitive and non-competitive inhibitors. Biochem. J. 1974, 137, 143.

(34) Bernhard Schegel, H. Optimization of equilibrium geometries and transition structures. J. Comput. Chem. 1982, 3, 214-218.

(35) Becke, A. D. Becke's three parameter hybrid method using the LYP correlation functional. J. Chem. Phys. 1993, 98, 5648-5652.

(36) Lee, C.; Yang, W.; Parr, R. G. Development of the ColleSalvetti correlation-energy formula into a functional of the electron density. Phys. Rev. B 1988, 37, 785-789.

(37) Foster, J. P.; Weinhold, F. Natural hybrid orbitals. J. Am. Chem. Soc. 1980, 102, 7211-7218.

(38) Singh, U. C.; Kollman, P. A. An approach to computing electrostatic charges for molecules. J. Comput. Chem. 1984, 5, 129145.

(39) Chirlian, L. E.; Francl, M. M. Atomic charges derived from electrostatic potentials: A detailed study. J. Comput. Chem. 1987, 8, 894-905.

(40) Breneman, C. M.; Wiberg, K. B. Determining atom-centered monopoles from molecular electrostatic potentials. The need for high sampling density in formamide conformational analysis. J. Comput. Chem. 1990, 11, 361-373.

(41) Hu, H.; Lu, Z.; Yang, W. Fitting molecular electrostatic potentials from quantum mechanical calculations. J. Chem. Theory Comput 2007, 3, 1004-1013. 